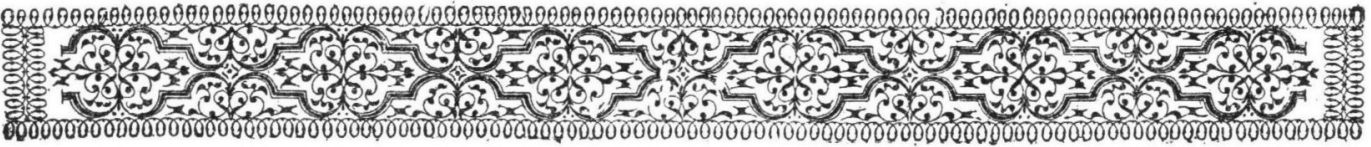

\title{
EEN REMBRANDT TE ROME
}

\author{
DOOR
}

Jhr. Dr. I. SIX.

OEN ik in Maart I 888 de verzameling in het paleis DoRIA vroeger
PAMPHILI te Rome bezocht, merkte ik daar een schilderij op die had ik geen werken bij mij om na te slaan of daaromtrent iets bekend was en ik veronderstelde dat de zaak lang onderzocht en uitgemaakt zou wezen. Ik teekende dus alleen in mijn BAEDEKER aall "24 studiekop van REMBRANDT $\pm \mathrm{I} 629 / 30^{\circ}$ en noemde het in een brief aan mijn vader "een echten, maar vroegen REMBRANDT, met een gewaagd lichteffect, als TI7IAAN vermeld."

Meer herinner ik mij thans nauwelijks omtrent dit stuk, maar ik wijs er op dat Michel in zijn opstel in Oud-Holland VIII (I 89o) over Francesco BALDinucci ét les biographes de Rembrandt, op blz. I68 meedeelt, dat van de twee schilderijen van REMBRANDT, die deze schrijver in Italie kent, het eene is: „à Rome, dans la Galerie PANFILI, une tete de vieillard portant une barbe courte et coiffé d'un turban". Ook RICHARDSON ${ }^{1}$ ) noemt na het beroemde portret van InNocentius $X$ van Velazquez het werk van Rembrandt met deze

1) Traité de la peinture et de la sculpture par Mrs. RiciIARdSon, Père et fils Amsterdam I 728 III. 563. 
woorden: On voit, à coté, un Portrait de REMBRANDT, à-peu-près du méme Caractève, par rapport à la manière particulière de colorier, et à la hardiesse du pinceau; mais il le surpasse en force, et beaucoup phus encore en harmonie et en beauté à l'égard des Teintes diférentes. Mij dunkt de zaak zou een nader onderzoek waard zijn.

Het feit zou zeker merkwaardig wezen dat een van de twee eenige schilderijen van REMBRANDT, die sedert $z \mathrm{ij}$ door een tijdgenoot van den meester vermeld werden, niet van plaats zijn verwisseld, tharıs in alle lijsten van zijn werken gemist wordt, terwijl het in een lange jaren gemakkelijk toegankelijke verzameling hangt in een stad waar meer kunstkenners zamen stroomen dan in eenige andere!

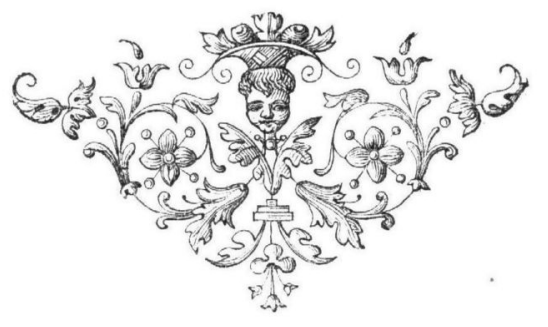

